\title{
PROSPECTIVES AND NECESSITY OF ERADICATION OF INFECTIOUS BOVINE RHINOTRACHEITIS / INFECTIOUS PUSTULAR VULVOVAGINITIS IN THE REPUBLIC OF SERBIA
}

Sava Lazić1 ${ }^{1}$, Tamaš Petrović ${ }^{1}$, Dejan Bugarski ${ }^{1}$, Milovan Jovičin ${ }^{1}$, Budimir Plavšić ${ }^{2}$, Diana Lupulović ${ }^{1}$, Gospava Lazić1, Vladimir Polaček ${ }^{1}$

${ }^{1}$ Scientific Veterinary Institute „Novi Sad“,Novi Sad

${ }^{2}$ Ministry of Agriculture and Environmental Protection, Veterinary Directorate,

\section{Abstract} Novi Beograd

Infectious bovine rhinotracheitis/infectious pustular vulvovaginitis (IBR/IPV) is a disease affecting cattle population of all breeds, categories and age. The disease can take different clinical courses, infectious bovine rhinotracheitis (IBR) and infectious pustular vulvovaginitis (IPV) being the most common ones. Both diseases, an especially infectious bovine rhinotracheitis (IBR), pose severe health threat and cause major economic losses and are considered one of the most costly diseases in cattle industry. The causal agent is a virus categorized into the family Hepesviridae and designated as bovine herpesvirus type 1 (BHV-1) or IBR/IPV virus. Any positive result to IBR/IPV specific antibodies in non-vaccinated cattle, in either blood or milk, indicates the infection, and the animal is considered a source of infection. In this article, we described the needs and prospects for the eradication of IBR/IPV in the Republic of Serbia. The eradication of IBR/ IPV is a complex process implying strictly defined program of measures. The implementation of such measures requires systematic strategy involving different phases and activities that can continue over several years. The program requires substantial efforts as well as financial resources, which should be justified and paid off through a successful eradication of IBR/IPV

Key words: IBR/IPV, eradication, prospectives, necessity

\footnotetext{
${ }^{1 *}$ Corresponding author: lazic@niv.ns.ac.rs
} 


\section{MOGUĆNOSTI I POTREBE ISKORENJIVANJA INFEKTIVNOG GOVEĐEG RINOTRAHEITISA/INFEKTIVNOG PUSTULOZNI VULVOVAGINITISA U REPUBLICI SRBIJI}

Sava Lazić1, Tamaš Petrović ${ }^{1}$, Dejan Bugarski ${ }^{1}$, Milovan Jovičin ${ }^{1}$, Budimir Plavšić ${ }^{2}$, Diana Lupulović ${ }^{1}$, Gospava Lazić1, Vladimir Polaček ${ }^{1}$

${ }^{1}$ Naučni institut za veterinarstvo „Novi Sad“, Novi Sad

${ }^{2}$ Ministarstvo poljoprivrede i zaštite životne sredine Republike Srbije, Uprava za veterinu,

Novi Beograd

\section{Kratak sadržaj}

Infektivni goveđi rinotraheitis/infektivni pustulozni vulvovaginitis (IBR/IPV) su bolesti od koje oboljevaju goveda svih rasa, kategorija i uzrasta. Bolest se klinički pojavljuje u više formi, ali najčešće pojave bolesti su infektivni goveđi rinotraheitis (IBR) i infektivni pustulozni vulvovaginitis (IPV). Obe forme bolesti, a posebno infektivni goveđi rinotraheitis (IBR), nanose velike zdravstvene i ekonomske gubitke, pa se IBR smatra jednom od „najskupljih bolesti” u govedarstvu. Uzročnik bolesti je virus. Sistematizovan je u familiju Hepesviridae i označen je kao goveđi herpesvirus tip 1 (BHV-1) ili kao IBR/IPV virus. Svaki nalaz antitela protiv IBR/IPV virusa kod nevakcinisanih goveda, bilo u krvi ili mleku, ukazuje da je grlo inficirano i da predstavlja izvor infekcije. U radu su predstavljene mogućnosti i potrebe iskorenjivanja IBR/IPV u Republici Srbiji. Iskorenjivanje IBR/IPV je proces i sprovodi se prema jasno definisanom programu, koji može da traje više godina, a čine ga više faza sa različitim aktivnostima. Sprovođenje programa zahteva veliki rad i značajna materijalna i finansijska sredstva, koja treba da budu opravdana i nadoknađena uspešnim iskorenjivanjem IBR/IPV.

Ključne reči: IBR/IPV, iskorenjivanje, perspektive, potreba

\section{INTRODUCTION}

Infectious bovine rhinotracheitis / infectious pustular vulvovaginitis (IBR/ IPV) is a disease affecting cattle population of all breeds, categories and age. The disease can take different clinical courses, infectious bovine rhinotracheitis (IBR) and infectious pustular vulvovaginitis (IPV) being the most common ones. Both clinical forms, an especially infectious bovine rhinotracheitis (IBR) brings on severe health threat and substantial economic losses and is considered one of the most costly diseases in cattle industry. The causal agent is a virus from the family of Herpesviridae, sub-family Alphaherpesviridae, named according to the clinical diseases it caused - bovine herpesvirus type 1 (BHV-1) or IBR/IPV virus. 
$\mathrm{IBR} / \mathrm{IPV}$ is an issue of major importance from both health and economic point of view. Acute form of IBR is associated with severe health risk and considerable economic damage. The initial disease manifestations involve rhinotracheitis and keratoconjunctivitis, which in turn progress to severe bronchopneumonia. Most severely affected animal populations are young cattle categories, i.e., calves and bull calves. Some animals that survive the acute form of the disease manifest apparent developmental defects as a consequence of severe injury of respiratory organs, especially lungs. In adult animals, that is, cows and in-calf heifers, in addition to respiratory syndrome, the infection can result in abortion, fetal mortality, prolonged service period and decreased milk yield (Von Krage E et al., 1989; Hagee JJ et al., 1996; Hagee JJ et al., 1998; Graham A.David 2013). Establishment of latent infection in all animals that survived the acute form is highly characteristic for the disease. Latently infected animals do not manifest clinical signs of the disease, while presence of virus-specific antibodies is the only indicator that the animal is potential infection reservoir. Moreover, a loss in milk yield of some $0.9 \mathrm{~kg} /$ day during nine weeks has been established in latently infected cows (Straub Ch.O., 2001). In addition to these and many other direct losses, latent IBR/IPV infection can cause a range of rather non-quantifiable indirect losses. Some typical examples include bans on trading breeding cattle, semen and embryos originating from infected herds or even regions. Such bans may bring even greater losses than the IBR/IPC epidemics itself.

With an aim of preventing the occurrence of the disease and consequential economic losses the problem of IBR/IPV has been addressed by a range of researchers worldwide. Extensive researches have been conducted to determine disease prevalence mainly because of its latent form and its importance for cattle trading. By the end of $20^{\text {th }}$ century, numerous countries developed and implemented relevant programs for eradication of IBR/IPV to enable an unhindered cattle trading. Low incidence of IBR/IPV among cattle herds in Switzerland, Austria, Denmark and all Scandinavian countries resulted in complete eradication of IBR/IPV and obtaining of IBR/IPV-free status. Such status granted the aforementioned countries possibility of free international trading with all cattle categories as well as with semen for artificial insemination (Ackermann M., Engels M., 2006). Some other EU Member States have put substantial effort to eradicate the disease and obtain IBR/IPV free status in clearly delineated territories. Thus, the region of Bayern in Germany and Bolzano in Italy are nowadays certified as regions free from IBR/IPV. Moreover, all EU Member States developed and implemented their own national programs for eradication and control of IBR/IPV (Ackermann M., Engels M., 2006). Some of 
them, such as Germany, Poland, Slovakia, Slovenia, Czech Republic, Hungary etc., eradicated IBR/IPV in almost all regions and are close to declaring the IBR/IPV-free status in either entire territory or at least some regions. According to OIE records, an outbreak of IB/IPV was established by the beginning 2015 in Austria, which had been considered IBR/IPV-free country since 2004. IBR/IPV was detected in 27 herds from four Austrian regions - Vorarlberg (3), Tyrol (18), Upper Austria (1) and Lower Austria (5).

The investigation of IBR/IPV in the Republic of Serbia was initiated in the 60ties of the last century. In 1967, Bratanović U et al. isolated the virus, which was the first isolation of IBR/IPV in our country. Later on, a number of researchers reported on isolation and seroprevalence of IBR/IPV in different cattle herds and regions in Serbia (Jermolenko G et al., 1978, Pavlović R et al., 1981, Lazić S et al., 1995, Lazić S et al., 2008.). It should be emphasized that many cattle herds in the Republic of Serbia have preserved an IBR/IPV-free status. Moreover, current farm practices among many farmers imply introducing only IBR/IPV-free animals into the newly-formed cattle herds. In that respect, we can state that certain number of cattle herds in the Republic of Serbia is considered IBR/IPV-free. Such herds can be certified as IBR/IPV free herds after relevant examination procedure.

\section{PROGRAMS FOR ERADICATION OF IBR/IPV}

Huge health-economic losses associated with IBR/IPV prompted a number of West-European countries to develop legal regulations and provisions for getting this infection under control. Eradication of IBR/IPV in many EU countries was carried out in line with the provisions of the Directives 64/432/ EEC, 2004/558/EEC and other relevant legislation. All countries interested in participation in international cattle trading were obligated to ensure development and implementation of national programs for control, suppression and eradication of IBR/IPV. Even if not the member of EU/EEC, Switzerland was one of the first countries in the world, which developed and implemented the program for control, suppression and eradication of IBR/IPV. (Bommeli W., Kihm U., 1982., Ackermann M., et al. 1990).

The program of eradication of IBR/IPV in Switzerland has continued throughout 10 years and was based on the principle "test and remove", without using vaccines. The eradication process in Switzerland prolonged over some 10 years including four simultaneous phases. With an aim of preventing disease transmission restrictions were imposed on trade of breeding animals with IBR/IPV positive finding. Such animals were sent to slaughter. All breed- 
ing and fattening animals were examined and animals with positive finding of IBR/IPV specific antibodies were slaughtered. Continuous monitoring has been conducted in order to maintain the status of IBR/IPV-free country.

Austria is also one of the first European countries that introduced the program for eradication of IBR/IPV. Since 1990, eradication has been mandatory for all cattle producers. Because of low seroprevalence, the eradication strategy of IBR/IPV included slaughtering of all seropositive animals without vaccination. Continuous monitoring is practiced in line with relevant legislation (Ackermann M., Engels M., 2006).

By the 1990s, Denmark, Finland, Norway and Sweden implemented successful programs for eradication of IBR/IPV and are now considered diseasefree states at their entire territory. Since the seroprevalence was relatively low, eradication strategy included slaughtering of seropositive animals without vaccination and with continuous surveillance by serological testing (Ackermann M., Engels M., 2006). The "test and slaughter"approach (Nuotio L. et al., 2007) was applied in all aforementioned countries.

Some other EU Member States such as Germany (except Bavaria), Italy (except region of Bolzano), Poland, Hungary, Slovenia, Ireland, Belgium, France, Netherlands, Portugal, Lithuania, Spain and Great Britain developed national programs for eradication of IBR/IPV based on vaccination (mostly using marker vaccines against IBR/IPV) and continuous monitoring of the disease. Many of those countries such as Germany (all regions), several provinces in Italy, Poland as well as Czech Republic, Slovakia and Slovenia have already completed or are close to complete eradication of IBR/IPV in all regions.

As emphasized by numerous authors, appropriate monitoring is the crucial element of an IBR/IPV eradication program. The monitoring defines the methods and manner of disease control. Serological testing is the key segment, thus, type and number of samples per one herd as well as the testing-intervals needs to be precisely defined (Graat E.A.M. et al., 2001, Knopf L. et al., 2007). Herd size, seroprevalence and the level of applied biosecurity measures are individual characteristics of each herd, which significantly affect the effectiveness of an eradication program disregarding the applied methods and model of eradication.

\section{ERADICATION OF IBR/IPV IN THE REPUBLIC OF SERBIA}

According to the research results from previous period as well as from current research, the presence of the disease is likely in many herds, and some $50 \%$ of cattle are suspected to be latently infected with IBR/IPV virus. 
The eradication of IBR/IPV in our country relies on voluntary participation of cattle owners, same as in majority of other countries that have already eradicated or are close to complete eradication of the disease, yet with the support and participation of governmental institutions in view of appropriate monitoring and certification. Herd certification is performed by Veterinary Directorate through relevant veterinary institutes, field veterinary service and under supervision of veterinary inspection board. Veterinary Directorate issues the certificate and keeps the Records on issued certificates. The certificates need to be available on-line from the web-site of the Veterinary Directorate and all relevant data on the herd, IBR/IPV eradication and validity date of the certificate should be visible for all interested parties.

Eradication of IBR/IPV is highly complex and comprehensive procedure encompassing several phases. Depending on disease prevalence within the herd the process can prolong over several years. Once the disease has been eradicated, continuous yearly monitoring is crucial for the maintenance of IBR/IPV free status of the herd as well as for preventing introduction and spreading of IBR/IPV virus within the herd. The surveillance can prevent a range of health problems while continuous monitoring confirms the IBR/IPV free status of the herd resulting in renewal of relevant certificates.

Initial phase, or phase I, encompasses the confirmation of the presence of the disease in the herd. The detection relies on examination of milk samples (bulk samples or individual samples) and/or blood serum testing. Bulk milk sample can contain milk samples collected from up to 20 cows. The size of the herd, that is, number of cattle in the herd, determines the number of samples/ animals to be examined in order to confirm the presence of the disease. If the presence of the disease has not been confirmed in milk samples, blood samples are collected from non-milking cows (dry cows and all other animals older than 2 months) in order to determine herd disease status. Negative findings for IBR/IPV virus in milk and blood samples are argumentative enough to confirm absence of the infection, i.e., to consider the herd free from IBR/IPV. The herd can be certified as IBR/IPV-free.

Positive finding of antibodies against IBR/IPV virus in milk samples requires precise determination of disease prevalence within the herd in order to define the program, i.e., the method and procedures for eradication of the disease. Precise determination of seroprevalence encompasses testing of individual milk samples and blood samples from strictly defined number of animals. The crucial factor for the determination of prevalence is the number of examined animals in the herd calculated using Cannon's formula (Cannon R.M. 2001) which is applicable for a reliable determination of seroprevalence 
at herd level. According to the prevalence value, either physical removal of infected animals or vaccination is applied. Removal (culling) of infected animals from the herd is justified with prevalence rates below $5 \%$. Removal of latently infected animals is considered the most effective method for eradication of IBR/IPV. After removing the last infected bovine from the herd, dual control is performed after 28-day period (two incubation periods) and should include all animals in the herd. Obtaining of two successive negative results at both testings qualifies the herd for certification as IBR-free.

In conditions of high disease prevalence, vaccination is considered the most suitable instrument for eradication of IBR/IPV. Vaccination needs to be well planned and comprehensive, and must include all cattle categories. The vaccination schedule is determined according to the type of selected vaccine. Vaccination should be conducted throughout the period of several years, that is, until removing all latently infected animals from the herd. Monitoring of vaccination effects should be performed throughout the entire vaccination period to determine the IBR/IPV status of the herd. In the eradication of IBR/ IPV, very good results were obtained with the vaccine containing glycoprotein E-deleted $(g E)$ gene, so-called IBR/IPV marker vaccine, which was developed for usage in IBR/IPV eradication programs. Application of this marker vaccine enables differentiation between vaccinated and infected animals (DIVA principle) during the monitoring process - testing of seroconversion and vaccination effects using appropriate diagnostic tools. This provides useful information on disease status within the herd, i.e., stagnation or progress. Successful eradication of IBR/IPV using marker vaccine has been accomplished in many bovine herds in EU.

In the process of eradication of IBR/IPV, vaccination period and schedule are determined by herd overhaul plan. It usually lasts $4-5$ years, as it is likely that some $20-25 \%$ of all latently infected animals will be eliminated from the herd. Monitoring is performed one year post vaccination encompassing examination of bulk milk samples and blood samples from non-milking animals. Negative finding qualify the herd for certification as IBR/IPV free.

The maintenance of certified IBR/IPV-free status implicates continuous adherence to relevant biosecurity measures, monitoring of health status and periodic control of blood samples and bulk milk samples. Implementation and adhering to relevant biosecurity measures is crucial to the prevention of numerous diseases including IBR/IPV. Newly purchased animals are potential entry portal for many diseases, thus, purchase of new animals should be performed only from herds certified as free from IBR/IPV. Such animals must be quarantined prior to be introduced into the herd. Isolation period can extend 
even up to one month, that is, until obtaining laboratory confirmation on IBR/ IPV virus-free status for all purchased bovines. Monitoring of animals' health status implies exclusion of IBR/IPV virus as a causal agent in cases of abortion, fetal mortality and manifested respiratory syndrome in the herd. Control examination is one of the most important factors for maintenance of IBR/IPV free status. Such examination encompasses detection of IBR/IPV specific antibodies in blood and/or milk samples as reliable indicators of the disease and is performed at 6-month intervals. The number of examined animals to be examined is determined according to herd size applying Cannon's formula, and must be representative at herd level. These activities ensure the certification of the herd, which needs to be documented by relevant record of issued by authorized institutions, describing all activities performed in a certified IBR/ IPV-free cattle herd.

\section{CONCLUSIVE REMARKS}

Eradication of IBR/IPV in the Republic of Serbia is absolutely indispensable and economically justified. It offers multiple benefits, above all for producers of breeding material but also for other economic branches such as dairy and meat industry as well as other business entities involved in cattle industry either directly or indirectly. Having in mind the complex nature of program implementation, it is essential to identify the participating subjects and their responsibilities. Cattle owners (farmers, cooperative societies, associations) play the major role in the process. Eradication of IBR/IPV should be voluntary for farmers and not the subject of coercive measures.

Aside from farmers, successful realization of the program requires participation of other subjects such as field veterinary service, veterinary inspection board, relevant departments of scientific or specialized veterinary institutes and Veterinary Directorate. Farmers and field veterinarians assisted by professionals from veterinary institutes and under supervision of veterinary inspection board launch the initiative and submit the request for eradication of IBR/IPV to the Veterinary Directorate. After obtaining positive response, professionals from veterinary institutes develop detailed program of activities in cooperation with field veterinary service and farmers and under supervision of veterinary inspection board. Field veterinary service in cooperation with farmers performs the sampling and submission of samples to the relevant veterinary institute under supervision of veterinary inspection board. If the eradication of infection requires vaccination, field veterinary service is responsible to supply the vaccines and carry out the vaccination according to vaccination 
schedule designed by professionals from veterinary institutes. Testing results, opinions and recommendation on IBR/IPV eradication of the relevant veterinary institute are submitted to farmers, field veterinary service and veterinary inspection board. At the moment of termination of the program, relevant veterinary institute and veterinary inspection board submits to the Veterinary Directorate relevant documentation and the proposal for certification of the herd as IBR/IPV-free. Veterinary Directorate issues the certificate and keeps the Records on issued certificates. The certificates need to be available from the web-site of the Veterinary Directorate („on-line“).

\section{ACKNOWLEDGMENTS}

This work is conducted within the project TR31084 funded by the Serbian Ministry of Education, Science and Technological development.

\section{REFERENCES}

1. Ackermann M., Engels M.: Pro and contra IBR-eradication, Veterinary Microbiology, 113, 293-302, 2006.

2. Ackermann M., Müller H.K., Bruckner L., Kihm U.: Eradication of infectious bovine rhinotracheitis in Switzerland: review and prospects, Vet. $\mathrm{Mi}$ crobiol., 23, 1-4, 365-370, 1990.

3. Bommeli W. and Kihm U.: The IBR control programme in Switzerland, XIIth World congres on diseases of cattle The Netherlands, Vol. I, 153-156, 1982.

4. Cannon R.M.: Sense and sensitivity - designing surveys based an an imperfect test, Preventive Veterinary Medicine, 49, 141-163, 2001.

5. Graat E.A.M., de Jong M.C.M., Frankena K., Franken P.: Modelling the effect of surveillance programmes an spread of bovine herpesvirus 1 between certified cattle herds, Veterinary Microbiology, 79, 193-208, 2001.

6. Grham A. David: Bovine herpes virus-1 (BoHV-1) in cattle-a review with emphasis an reproductive impacts and the emergence of infection in Irland and the United Kingdom, Irish Veterinary Journal, 66, 1-11, 2013.

7. Hage J.J., Schukken Y.H., Barkema H.W., Benedictus G., Rijsewijk F.A.M., Wentink G.H.: Population dynamics of bovine herpesvirus 1 infection in a dairy herd, Veterinary Microbiology 53, 169-180, 1996.

8. Hage J.J., Schukken Y.H., Dijkstra Th., Barkema H.W., , van Valkengoed P.H.R., Wentink G.H.: Milk production and reproduction during a subclinical bovine herpesvirus 1 infection on a dairy farm, Preventive Veterinary Medicine 34, 97-106, 1998. 
9. Jermolenko G., Vujović R., Radosavljević D.: Rezultati trogodišnjeg ispitivanja proširenosti IBR/IPV infekcije na područiju uže Srbije, Vet. glasnik, 5, 409-413, 1978.

10. Knopf L., Schwermer H., Stärk K.DC.: A stochastic simulation model to determine the sample size of repeated national surveys to document freedom from bovine herpesvirus I (BoHV-I) infection, BMC Veterinary Research, 3:10, doi: 10.1186/1746-6I48-3-10, 2007.

11. Lazić S., Pavlović R., Lalić M., Đurišić S., Jovičin M:: Rasprostranjenost infekcije izazvane goveđim herpesvirusom-1 u matičnim zapatima goveda Vojvodine u 1992. i 1993. godini, Vet. glasnik, 49, (2-3), 99-103, 1995.

12. Lazić S., Petrović T., Lupulović D., Bugarski D., Pušić I., Polaček V., Maljković M.: Raširenost infekcije herpesvirusom1 u malim zapatima goveda na području Južnobačkog i Sremskog okruga, Arhiv veterinarske medicine, vol. 1, 1, 18-31, 2008.

13. Nuotio L., Neuvonen E., Hyytiäinen M.: Epidemiology and eradication if infectious bovine rhinotrcheitis/infectious pustular vulvovaginitis (IBR/ IPV) virus in Filand, Acta Veterinaria Scandinavica, 49:3, 1-6, 2007.

14. Pavlović R., Veselinović S., Đurišić S., Milivojević D., Lalić M., Jakšić N., Normali M.,: Infekcije sa IBR i PI-3 virusima tovne junadi i krava nekih matičnih zapata u SAP Vojvodini u periodu 1975.-1980. U: Zbornik radova, Veterinarski institut Novi Sad, 49-53, 1981.

15. Straub Ch. Otto: Advances in BHV-1 (IBR) reasearch, Dutch. Tierarztl. Wachr., 108, 419-422, 2001.

16. Von Krage, E., Tezffert, J., Ziegler, L., Bergmann, H.: Die okologische bedeutung der bovid-herpes-virus-1 infection des rindes, Monatschrift fur Veterinarmedizin, 2, 41-44, 1989.

Primljeno: 20.07.2016.

Odobreno: 15.09.2016. 